\title{
OPTIMIZATION OF GAS TURBINE POWER PLANT BY EVOLOUTIONARY ALGORITHM; CONSIDERING EXERGY, ECONOMIC AND ENVIRONMENTAL ASPECTS
}

\author{
Moein Shamoushaki ${ }^{1,}$ M.A. Ehyaei ${ }^{2, *}$
}

\begin{abstract}
In this paper the exergy, economic and environmental analysis of Aliabad Katoul power plant as well as its multiobjective optimization have been done by NSGA-II algorithm. Two objective functions have been considered. The first objective function is the total cost rate and the second objective function is environmental impact cost. Optimization of objective functions has been done in two modes namely cycle with and without air preheater. The results showed that the existence of air preheater reduces both objective functions. So that in optimum point, for cycle without air preheater, the amount of total cost rate has been about $30 \%$ and environmental cost rate was about $33 \%$ higher than cycle with air preheater. Also, sensitive analysis of objective functions to fuel unit cost was conducted. At the lower environmental cost rate that the total cost rate was higher, sensitivity of Pareto solutions to the fuel unit cost was more than some parts of figure with smaller total cost rate. Also, exergy losses of various components were obtained that conclusions illustrated that combustion chamber has the maximum rate of exergy destruction (about 73\%). Impact of ambient temperature variation on exergy losses and efficiency for different components was studied. The conclusions illustrated that with growing in ambient temperature, exergy efficiency of all parts decreased and exergy losses increased. Also, by rising the ambient temperature, exergy efficiency decreased, so that an increase in temperature from 293 Kelvin to 323 Kelvin, total exergy efficiency decreased from about $51 \%$ to $49 \%$.
\end{abstract}

Keywords: Gas Turbine, Exergy, Sensitive, Environmental, NSGA-II

\section{INTRODUCTION}

In preceding years, according to the rising energy expenses and environmental damages, using of the systems with higher efficiency and lower pollution have attracted researchers' attention. Also, global warming and its side effects on environment is one of the major challenges confronting humanity. Gas turbine power plants have a considerable role in energy production for the industry. Therefore, a gas turbine cycle analysis in terms of thermodynamic, environmental and economic aspects is necessary. Kopac and Hilaci in 2007 the authors investigated an energy model for a thermal power plant in Turkey to consider the impact of ambient temperature on irreversibility and second law efficiency of the power plant components [1]. Sahoo in 2008 the author did exergy-economic analysis and optimization of a combined heat and power system. He studied the $50 \mathrm{MW}$ of power plant which it produces $15 \mathrm{~kg}$ of saturated steam at a pressure of 2.5 Bars [2]. Ehyaei et al. in 2011 studied inlet fogging system effects on first and second law efficiencies for a gas turbine power plant located in Iran [3]. Ahmadi et al in 2011 conducted the exergy, exergoeconomic and environmental analyses and evolutionary algorithm based multi-objective optimization of combined cycle power plants [4]. Ganjeh Kaviri et al in 2012 performed thermodynamic analysis of a dual pressure CHP system [5]. Ahmadi et al. in 2012 conducted multiobjective optimization considering second law of thermodynamics for a cogeneration system [6]. Ahmadi et al. in 2012 studied energy modeling and multi-objective optimization of a polygeneration power plant [7]. Shirazi et al. in 2012 conducted energy, exergy, economic and environmental analysis of gas turbine cycle with fuel cell and internal reforming [8]. Ahmadi et al. in 2013 performed thermodynamic modeling and optimization of a new multi-generation energy system [9]. Memon et al. in 2013 conducted a gas turbine cycle modeling. They also studied the effects of major performance

This paper was recommended for publication in revised form by Regional Editor Mustafa Kilic

1 Department of Mechanical Engineering, Science and Research Branch, Islamic Azad University, Iran

${ }^{2}$ Department of Mechanical Engineering, Pardis Branch, Islamic Azad University, Pardis New City, Iran

${ }^{*}$ E-mail address: aliehyaei@yahoo.com

Orcid id: 0000-0002-4721-9427

Manuscript Received 03 May 2018, Accepted 13 July 2018 
parameters on the overall cycle efficiency and $\mathrm{CO}_{2}$ emissions [10]. Majdi Yazdi et al. in 2015 examined the use of a heat pump for reduction the gas turbine compressor inlet air temperature [11]. Ehyaei et al. in 2015 studied inlet air fogging system on the first and second law efficiency and net output power of a combined cycle power plant [12]. Khaljani et al. in 2015 carried out thermodynamic, exergy-economic and environmental aspects of a hybrid system included gas turbine and organic Rankine cycle [13]. Also, several papers about the exergy, economic and environmental analysis of power production system have been investigated in recent years [3,11, 12, 14-45].

Up to now, no research has been done about the optimization and result comparison of a gas turbine power plant with and without air preheater. In previous studies that have been done by other researches, only one type of gas turbine power plant has been studied. Also, a real power plant (Aliabad Katoul) has been studied in this research.

In this paper, the thermodynamic, exergoeconomic and exergoenvironmental analysis of Aliabad Katoul gas turbine power plant (northern Iran) and its optimization by multi-objective genetic algorithm (NSGA-II) has been carried out in MATLAB software. Each unit of the power plant generates $150 \mathrm{MW}$ of electricity. This power plant has six units and overall generates $900 \mathrm{MW}$ electricity. The weather (which the power plant is located) is moderate and wet region. Two objective functions have been intended in this research. The first objective function is the total cost rate including fuel cost rate, investment and maintenance cost rate and exergy destruction cost rate. The other objective function is cost of environmental impacts. The main components of the cycle include air compressor, combustion chamber, gas turbine and air preheater. The design variables considered in this study include: pressure ratio of air compressor $\left(r_{A C}\right)$, combustion chamber inlet temperature $\left(T_{3}\right)$, inlet temperature of gas turbine $\left(T_{4}\right)$, air compressor isentropic efficiency $\left(\eta_{A C}\right)$ and gas turbine isentropic efficiency $\left(\eta_{G T}\right)$. Also, impact of air preheater presence on two objective functions has been investigated. The second intended case, cycle do not have air preheater that in this case, four design variables have been considered that are pressure ratio of air compressor, gas turbine inlet temperature, air compressor and gas turbine isentropic efficiency. Also, sensitivity analysis and the impact of fuel cost per unit of energy on objective functions have been considered. The effect of inlet air temperature change on exergy efficiency and destruction of each part as well as its impact on the exergy efficiency has been investigated. In summary, the following works have been done in this paper:

- Doing exergy, exergoeconomic and exergoenvironmental analysis of gas turbine cycle and its optimization with multi-objective genetic algorithm in MATLAB

- Comparing the values of objective functions for gas turbine cycle in both cases with air preheater and without air preheater and comparison of the results

- Sensitivity analysis of fuel cost per unit of energy and its impact on the objective functions

- Calculating the exergy destruction of various parts of the cycle

- Investigating the ambient temperature impact on exergy efficiency of each part, overall exergy efficiency and exergy destruction for each part.

\section{MATHEMATICAL MODELING}

\section{ENERGY ANALYSIS}

First, thermodynamic modeling of the cycle has been done. This modeling is obtained by writing the first law of thermodynamic and the balance of mass and energy equations for each component. In present analysis, the following assumptions have been assumed:

- The air and exhaust gases have been assumed to be ideal gas.

- The inlet air temperature of air compressor has been considered equal to $298 \mathrm{~K}$ and its pressure is $1.013 \mathrm{bar}$ [6].

- All cycle parts have been assumed to be steady state.

- Pressure drop in air preheater for air has been considered to be 5\% and 3\% difference in pressure between input and output has been considered for combustion products [6].

- Heat loss from the combustion chamber has been considered equal to $5 \%$ low fuel heating value [6].

- The value of $C_{p}$ is considered constant with temperature changes. 
The figures of gas turbine cycle related to Aliabad Katoul power plant with and without air preheater have been illustrated in Figure 1 and Figure 2. In these figures, air is compressed in air compressor (AC). Then compressed air is reacted with natural gas in combustion chamber $(\mathrm{CC})$. Exhaust hot gas from combustion chamber, rotates gas turbine (GT) and it generates electrical power. In cycle with air preheater (APH) exhaust hot gas from gas turbine heats compressed air before it enters the combustion chamber.

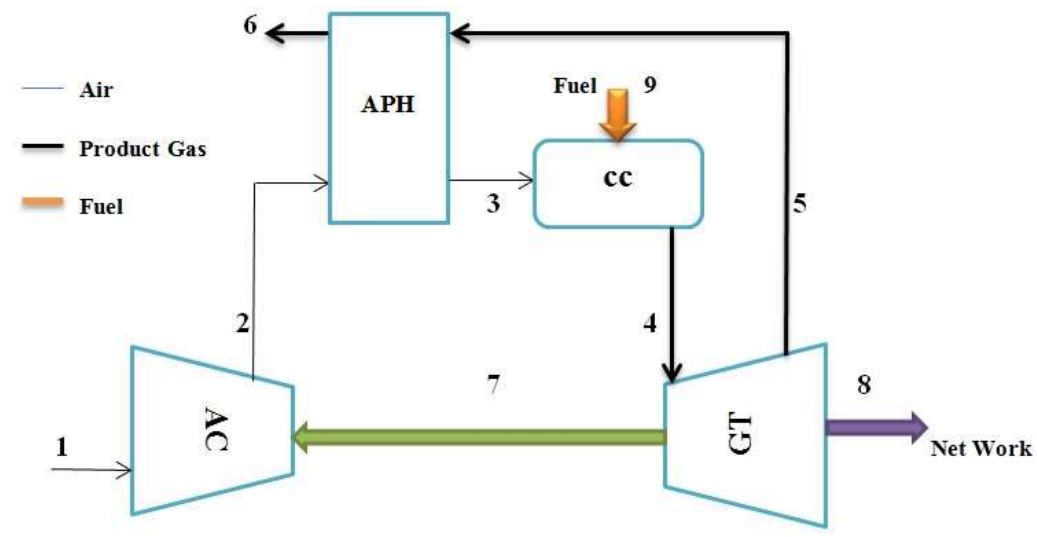

Figure 1. Aliabad Katoul gas turbine power plant

Energy equations for each component are as follows:

Air compressor:

$$
\begin{gathered}
\mathrm{T}_{2}=\mathrm{T}_{1}\left\{1+\frac{1}{\eta_{\mathrm{AC}}}\left[\frac{\mathrm{P}_{2}}{\mathrm{P}_{1}}\right]^{\frac{\gamma_{\mathrm{a}}-1}{\gamma_{\mathrm{a}}}}-1\right\} \\
\dot{W}_{A C}=\dot{m}_{a} c_{p, a}\left(T_{2}-T_{1}\right)
\end{gathered}
$$

At the above equations, $\dot{W}_{A C}$ is air compressor net work.

Air preheater:

$$
\begin{gathered}
\dot{m}_{a} c_{p, a}\left(T_{3}-T_{2}\right)=\dot{m}_{g} c_{p, g}\left(T_{5}-T_{6}\right) \\
P_{3}=P_{2}\left(1-\Delta P_{\mathrm{a}, \mathrm{APH}}\right) \\
P_{6}=P_{5}\left(1-\Delta P_{\mathrm{g}, \mathrm{APH}}\right)
\end{gathered}
$$

Combustion chamber:

$$
\begin{gathered}
\dot{m}_{a} h_{3}+\dot{m}_{f} L H V=\dot{m}_{g} h_{4}+\left(1-\eta_{C C}\right) \dot{m}_{f} L H V, \quad \eta_{C C}=0.95 \\
P_{4}=P_{3}\left(1-\Delta P_{\mathrm{CC}}\right) \text { with } \Delta P_{\mathrm{CC}}=0.05 \mathrm{Bar}
\end{gathered}
$$


Here, LHV is fuel lower heating value that has been considered $50000(\mathrm{~kJ} / \mathrm{kg})$ for methane. The chemical balance of combustion in chamber is as follows:

$$
\begin{aligned}
& \left(0.81 \mathrm{CH}_{4}+0.079 \mathrm{C}_{2} \mathrm{H}_{6}+0.042 \mathrm{C}_{3} \mathrm{H}_{8}+0.047 \mathrm{C}_{4} \mathrm{H}_{10}+0.01 \mathrm{~N}_{2}+0.012 \mathrm{CO}_{2}\right)+2.412 \frac{1}{f}\left(\mathrm{O}_{2}+3.76 \mathrm{~N}_{2}\right) \rightarrow \\
& 1.294 \mathrm{CO}_{2}+2.56 \mathrm{H}_{2} \mathrm{O}+\left(2.412 r_{a}-2.562\right) \mathrm{O}_{2}+\left(0.01+9.06912 r_{a}\right) \mathrm{N}_{2}
\end{aligned}
$$

In the above equation, $f$ is fuel to air molar ratio.

$$
f=\frac{n_{\text {fuel }}}{n_{\text {air }}}
$$

By multiplying molar ratio into molar mass, the mass ratio obtains.

Gas turbine:

$$
\begin{gathered}
T_{5}=T_{4}\left\{1-\eta_{G T}\left[1-\left[\frac{P_{4}}{P_{5}}\right]^{\frac{1-\gamma_{g}}{\gamma_{g}}}\right]\right\} \\
\dot{W}_{G T}=\dot{m}_{g} c_{p, g}\left(T_{4}-T_{5}\right) \\
\dot{m}_{g}=\dot{m}_{a}+\dot{m}_{f} \\
\dot{W}_{n e t}=\dot{W}_{G T}-\dot{W}_{A C} \text { with } \dot{W}_{n e t}=150 \mathrm{MW}
\end{gathered}
$$

In the above equations, $\eta_{G T}$ is the isentropic efficiency of gas turbine, $\dot{W}_{G T}$ and $\dot{W}_{n e t}$ are the gas turbine net-work (MW) and net-work of cycle (MW), respectively. By solving the above equations, properties and thermodynamic values of different parts are obtained. Figure 2 shows the second considered cycle (without air preheater) that is as follows:
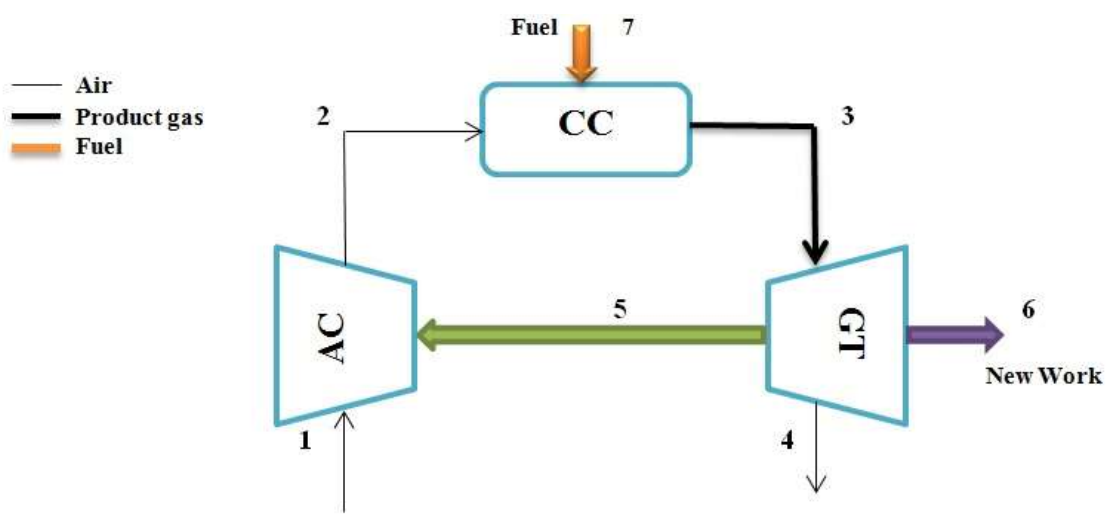

Figure 2. The gas turbine cycle of Aliabad Katoul power plant without air preheater 


\section{EXERGY ANALYSIS}

Exergy is divided to four sections: Physical, Chemical, Kinetic and Potentials. Kinetic and potential exergies are neglected in this study although they have not any noticeable effects on system analysis. By applying the first and the second laws of thermodynamics, the following exergy balance is obtained. Formula for exergy balance is as the following [46]:

$$
\dot{E} x=\dot{E} x_{p h}+\dot{E} x_{c h}
$$

The equations of physical and chemical exergy per unit mass are as follows [46]:

$$
e x_{p h}=\left(h-h_{0}\right)-T_{0}\left(s-s_{0}\right)
$$

Also, for mixed chemical exergy per unit mass we have [46]:

$$
e x_{\text {mix }}^{c h}=\left[\sum_{i=1}^{n} X_{i} e x^{c h_{i}}+R T_{0} \sum_{i=1}^{n} X_{i} \operatorname{Ln} X_{i}\right]
$$

The equations of exergy destruction and efficiency of different components of gas turbine cycle have been listed

\begin{tabular}{|c|c|c|c|}
\hline Components & Cycle & Exergy efficiency (\%) & Exergy destruction (MW) \\
\hline \multirow[t]{2}{*}{ Air compressor } & With APH & $\eta_{e x, A C}=\frac{\dot{\mathrm{E}}_{2}-\dot{\mathrm{E}}_{1}}{\dot{\mathrm{W}}_{\mathrm{AC}}}$ & $\dot{E}_{D, A C}=\dot{E}_{1}-\dot{E}_{2}-\dot{\mathrm{W}}_{\mathrm{AC}}$ \\
\hline & $\begin{array}{l}\text { Without } \\
\text { APH }\end{array}$ & $\eta_{e x, A C}=\frac{\dot{\mathrm{E}}_{2}-\dot{\mathrm{E}}_{1}}{\dot{\mathrm{W}}_{\mathrm{AC}}}$ & $\dot{E}_{D, A C}=\dot{E}_{1}-\dot{E}_{2}-\dot{\mathrm{W}}_{\mathrm{AC}}$ \\
\hline \multirow{2}{*}{$\begin{array}{l}\text { Combustion } \\
\text { chamber }\end{array}$} & With APH & $\eta_{e x, C C}=\frac{\dot{\mathrm{E}}_{4}}{\dot{\mathrm{E}}_{3}+\dot{\mathrm{E}}_{9}}$ & $\dot{E}_{D, C C}=\dot{E}_{3}+\dot{E}_{9}-\dot{E}_{4}$ \\
\hline & $\begin{array}{l}\text { Without } \\
\text { APH }\end{array}$ & $\eta_{e x, C C}=\frac{\dot{\mathrm{E}}_{3}}{\dot{\mathrm{E}}_{2}+\dot{\mathrm{E}}_{7}}$ & $\dot{E}_{D, C C}=\dot{E}_{2}+\dot{E}_{7}-\dot{E}_{3}$ \\
\hline \multirow[t]{2}{*}{ Gas turbine } & With APH & $\eta_{e x, G T}=\frac{\dot{\mathrm{W}}_{\mathrm{GT}}}{\dot{\mathrm{E}}_{4}-\dot{\mathrm{E}}_{5}}$ & $\dot{E}_{D, G T}=\dot{E}_{4}-\dot{E}_{5}-\dot{\mathrm{W}}_{\mathrm{GT}}$ \\
\hline & $\begin{array}{l}\text { Without } \\
\text { APH }\end{array}$ & $\eta_{e x, G T}=\frac{\dot{\mathrm{W}}_{\mathrm{GT}}}{\dot{\mathrm{E}}_{3}-\dot{\mathrm{E}}_{4}}$ & $\dot{E}_{D, G T}=\dot{E}_{3}-\dot{E}_{4}-\dot{\mathrm{W}}_{\mathrm{GT}}$ \\
\hline \multirow[t]{2}{*}{ Air preheater } & With APH & $\eta_{e x, A P H}=1-\left(\dot{\mathrm{E}}_{\mathrm{D}, \mathrm{APH}} / \sum_{\mathrm{i}, \mathrm{APH}} \dot{\mathrm{E}}\right)$ & $\begin{aligned} \dot{E}_{D, A P H}=\left(\dot{E}_{2}+\right. & \left.\dot{E}_{5}\right) \\
& -\left(\dot{E}_{3}+\dot{E}_{6}\right)\end{aligned}$ \\
\hline & $\begin{array}{l}\text { Without } \\
\text { APH }\end{array}$ & - & - \\
\hline
\end{tabular}
in Table 1.

Table 1. Exergy destruction and efficiency equations for whole parts 


\section{EXERGOECONOMIC ANALYSIS}

In order to reach more affordable system with better performance, by combination of exergy and economic, a new concept was presented that is called exergo-economics. This concept first was presented by Valero and colleagues [47]. The purpose of exergo-economics analysis is calculation the cost flow and calculation of cost per unit of flow exergy. Exergy cost of products is used for economic cycle optimization. For a system, cost balance equation is as follows [47, 48]:

$$
\sum_{e} \dot{\mathrm{C}}_{\mathrm{e}, \mathrm{k}}+\dot{\mathrm{C}}_{\mathrm{w}, \mathrm{k}}=\dot{\mathrm{C}}_{\mathrm{q}, \mathrm{k}}+\sum_{\mathrm{i}} \dot{\mathrm{C}}_{\mathrm{i}, \mathrm{k}}+\dot{\mathrm{Z}}_{\mathrm{k}}
$$

Using equation 16 , we can write $[47,48]$ :

$$
\begin{gathered}
\sum\left(c_{e} \dot{E} x_{e}\right)_{k}+c_{w, k} \dot{W}_{k}=c_{q, k} \dot{E} x_{q, k}+\sum\left(c_{i} \dot{E} x_{i}\right)_{k}+\dot{Z}_{k} \\
\dot{C}_{j}=c_{j} E_{j}
\end{gathered}
$$

At the above equations, $c_{i}$ is input exergy unit cost $(\$ / \mathrm{MJ}), c_{e}$ is output exergy unit cost (\$/MJ), $c_{w, k}$ is the cost rate for $\mathrm{K}^{\text {th }}$ flow line ( $\$$ / MJ) and $c_{q, k}$ is exergy unit cost related to the heat for $\mathrm{K}^{\text {th }}$ flow line $(\$ / \mathrm{MJ})$. Also, $C_{j}$ and $c_{j}$ are respectively, flow cost rate and exergy unit cost for the $\mathrm{j}^{\text {th }}$ flow line. In Eq. 15, no term is directly related to exergy destruction rate. So, by combining exergy balance equation and exergo-economic equation, cost of exergy destruction rate can be calculated.

$$
\begin{gathered}
\dot{E} x_{F, k}=\dot{E} x_{p, k}+\dot{E} x_{D, k} \\
\dot{C}_{F, k}=c_{F, k} \dot{E} x_{D, k} \\
\dot{C}_{P, k}=c_{P, k} \dot{E} x_{D, k}
\end{gathered}
$$

Where, $\dot{C}_{F, k}$ is the fuel cost rate $(\$ / \mathrm{s})$ and $\dot{C}_{P, k}$ is the products cost rate $(\$ / \mathrm{s})$. To solve cost balance equations and determine exergy rate of each system component, the component cost should be definite. In equation $16, \dot{Z}_{k}$ is the total investment and maintenance cost rate of each component. For each line, a flow cost rate has been defined. Exergy destruction cost rate is computed from the following equation:

$$
\dot{C}_{D, k}=c_{F, k} \dot{E} x_{D, k}
$$

In this equation, $\dot{C}_{D, k}(\$ / \mathrm{s})$ is the exergy destruction cost rate in $\mathrm{k}^{\text {th }}$ part of the system $(\$ / \mathrm{s}), c_{F, k}$ is exergy unit cost for input routes of $\mathrm{k}^{\text {th }}$ part of the system $(\$ / \mathrm{MJ})$ and $\dot{E} x_{D, k}$ is exergy destruction rate of $\mathrm{k}^{\text {th }}$ part of the system. For calculation the investment cost including the cost of equipment purchase and maintenance the following equation has been used $[47,48]$ :

$$
\dot{Z}_{k}=Z_{k} C R F \varphi /(N \times 3600)
$$

In the above equation, $Z_{k}$ is the purchase cost for $\mathrm{k}^{\text {th }}$ part (US\$) that the equations related to each part has been brought in Table 2. Also, fixed values related to equations of Table 2 have been brought in Table 3. $\varphi$ is the maintenance 
coefficient that in this article it is considered equal to 1.06 [48]. $\mathrm{N}$ is the hours of power plant operation in a year $(8,000$ hours) and CRF is the return on capital coefficient that has been considered equal to 0.182 in this study [47, 48]. The following equation has been used to calculate the fuel cost rate [47, 48]:

$$
\dot{C}_{f}=c_{f} \dot{m}_{f} L H V
$$

In the above equation $\dot{C}_{f}$ is fuel cost per unit of energy that is considered $0.004(\mathrm{US} \$ / \mathrm{MJ})[48] . \dot{m}_{f}(\mathrm{~kg} / \mathrm{s})$ is fuel mass flow rate.

Table 2. Cost functions for each system component

\begin{tabular}{|c|c|}
\hline System Components & Capital or investment cost functions \\
\hline Air compressor & $\mathrm{Z}_{\mathrm{AC}}=\left(\frac{\mathrm{C}_{11} \dot{\mathrm{m}}_{\mathrm{a}}}{\mathrm{C}_{12}-\eta_{\mathrm{AC}}}\right)\left(\frac{\mathrm{P}_{2}}{\mathrm{P}_{1}}\right) \ln \left(\frac{\mathrm{P}_{2}}{\mathrm{P}_{1}}\right)$ \\
\hline Combustion chamber & $\mathrm{Z}_{\mathrm{CC}}=\left(\frac{\mathrm{C}_{21} \dot{\mathrm{m}}_{\mathrm{a}}}{\mathrm{C}_{22}-\frac{\mathrm{P}_{4}}{\mathrm{P}_{3}}}\right)\left[1+\operatorname{EXP}\left(\mathrm{C}_{23} \mathrm{~T}_{4}-\mathrm{C}_{24}\right)\right]$ \\
\hline Gas turbine & $\mathrm{Z}_{\mathrm{GT}}=\left(\frac{\mathrm{C}_{31} \dot{\mathrm{m}}_{\mathrm{g}}}{\mathrm{C}_{32}-\eta_{\mathrm{GT}}}\right) \ln \left(\frac{\mathrm{P}_{4}}{\mathrm{P}_{5}}\right)\left[1+\operatorname{EXP}\left(\mathrm{C}_{33} \mathrm{~T}_{4}-\mathrm{C}_{34}\right)\right]$ \\
\hline Air preheater & $\mathrm{Z}_{\mathrm{APH}}=\mathrm{C}_{41}\left(\frac{\dot{\mathrm{m}}_{\mathrm{g}}\left(\mathrm{h}_{5}-\mathrm{h}_{6}\right)}{(\mathrm{U})(\Delta \mathrm{TLM})}\right)^{0.6}$ \\
\hline
\end{tabular}

Table 3. Constants used in the equations of Table 2

\begin{tabular}{|c|c|}
\hline System Components & Constants \\
\hline Air compressor & $\mathrm{C}_{11}=39.5 \quad U S \$ /(\mathrm{kg} / \mathrm{s}) \quad, \quad \mathrm{C}_{12}=0.9$ \\
\hline Combustion chamber & $\begin{array}{c}\mathrm{C}_{21}=25.6 \text { US } \$ /(\mathrm{kg} / \mathrm{s}), \quad \mathrm{C}_{22}=0.995 \\
\mathrm{C}_{23}=0.018 \mathrm{~K}^{-1}, \quad \mathrm{C}_{24}=26.4\end{array}$ \\
\hline Gas turbine & $\begin{array}{c}\mathrm{C}_{31}=266.3 U S \$ /(\mathrm{kg} / \mathrm{s}), \quad \mathrm{C}_{32}=0.92 \\
\mathrm{C}_{33}=0.036 \mathrm{~K}^{-1}, \mathrm{C}_{33}=54.4\end{array}$ \\
\hline Air preheater & $\mathrm{C}_{41}=2290 \quad U S \$ / \mathrm{m}^{1.2} \quad, \quad U=0.018 \mathrm{~kW} /\left(\mathrm{m}^{2} \mathrm{~K}\right)$ \\
\hline
\end{tabular}

\section{EXERGOENVIRONMENTAL ANALYSIS}

In order to reduce environmental impacts, optimization of power generation systems and reducing fuel consumption and environmental impact have attracted the attention of researchers. Therefore, optimization of heating systems accordingly has been one of the most important issues in recent years. One of the main objects of this paper is to study the adverse impacts of $\mathrm{CO}$ and NOx emissions. Adiabatic flame temperature in the combustion primary zone is calculated by the following equation $[8,49]$ :

$$
T_{p z}=A \sigma^{\propto} \exp \left(\beta(\sigma+\lambda)^{2}\right) \pi^{x^{*}} \theta^{y^{*}} \psi^{z^{*}}
$$

In this equation, $\pi$ is dimensionless pressure $\left(P / P_{\text {ref }}\right), \theta$ is dimensionless temperature $\left(T / T_{\text {ref }}\right)$. Also, $\psi$ is atomic ratio $(\mathrm{H} / \mathrm{C})$ that for $\phi \leq 1$, we have $\sigma=\phi(\phi$ is the mass or molar ratio) and for $\phi \geq 1$, we have $\sigma=\phi-0.7$. Moreover, $\mathrm{x}, \mathrm{y}$ and $\mathrm{z}$ are quadric functions of $\sigma$. 
Journal of Thermal Engineering, Research Article, Vol. 6, No. 2, Special Issue 11, pp. 180-200, March, 2020

$$
\begin{aligned}
& x^{*}=a_{1}+b_{1} \sigma+c_{1} \sigma^{2} \\
& y^{*}=a_{2}+b_{2} \sigma+c_{2} \sigma^{2} \\
& z^{*}=a_{3}+b_{3} \sigma+c_{3} \sigma^{2}
\end{aligned}
$$

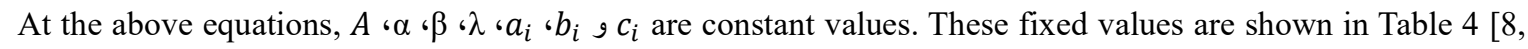
49]. The product of carbon monoxide and nitrogen oxide in combustion chamber changes with adiabatic flame temperature. For calculation the amount of pollution ( $\mathrm{g} / \mathrm{kg}$ of fuel), the following equation is used $[8,49]$ :

$$
\begin{gathered}
\dot{m}_{N O x}=\frac{0.15 \times 10^{16} \times \tau^{0.5} \times \exp \left(-71100 / T_{p z}\right)}{P_{3}^{0.05} \times(\Delta P / P)} \\
\dot{m}_{C O}=\frac{0.179 \times 10^{9} \times \exp \left(7800 / T_{p z}\right)}{P_{3}^{2} \times \tau \times(\Delta P / P)}
\end{gathered}
$$

At the above equations, $\tau$ is the residence time in the combustion zone that its amount has considered 0.002 seconds $[8,49] . P_{3}$ is inlet pressure of combustion chamber and $(\Delta P / P)$ is dimensionless pressure loss in the combustion chamber.

Table 4. Constants used in the equations 24 to 27

\begin{tabular}{|c|c|c|c|c|}
\hline \multirow{2}{*}{ Constants } & \multicolumn{2}{|c|}{$0.3 \leq \phi \leq 1.0$} & \multicolumn{2}{c|}{$1.0 \leq \phi \leq 1.6$} \\
\cline { 2 - 5 } & $0.92 \leq \theta \leq 2$ & $2 \leq \theta \leq 3.2$ & $0.92 \leq \theta \leq 2$ & $2 \leq \theta \leq 3.2$ \\
\hline$A$ & 2361.7644 & 2315.7520 & 916.8261 & 1246.1778 \\
\hline$\alpha$ & 0.1157 & -0.0493 & 0.2885 & 0.3819 \\
\hline$\beta$ & -0.9489 & -1.1141 & 0.1456 & 0.3479 \\
\hline$\lambda$ & -1.0976 & -1.1807 & -3.2771 & -2.0365 \\
\hline$a_{1}$ & 0.0143 & 0.0106 & 0.0311 & 0.0361 \\
\hline$b_{1}$ & -0.0553 & -0.0450 & -0.0780 & -0.0850 \\
\hline$c_{1}$ & 0.0526 & 0.0482 & 0.0497 & 0.0517 \\
\hline$a_{2}$ & 0.3955 & 0.5688 & 0.0254 & 0.0097 \\
\hline$b_{2}$ & -0.4417 & -0.5500 & 0.2602 & 0.5020 \\
\hline$c_{2}$ & 0.1410 & 0.1319 & -0.1318 & -0.2471 \\
\hline$a_{3}$ & 0.0052 & 0.0108 & 0.0042 & 0.0170 \\
\hline$b_{3}$ & -0.1289 & -0.1291 & -0.1781 & -0.1894 \\
\hline$c_{3}$ & 0.0827 & 0.0848 & 0.0980 & 0.1037 \\
\hline
\end{tabular}

\section{OBJECTIVE FUNCTIONS}

In this paper, the two objective functions have been considered. The first objective function is the total cost rate which is included fuel, investment and maintenance and exergy destruction cost rate which is as follows[47, 48]:

$$
\dot{C}_{T o t}=\dot{C}_{f}+\sum \dot{Z}_{k}+\sum \dot{C}_{D, k}
$$


In this equation, $\dot{\mathrm{C}}_{\mathrm{f}} \cdot \dot{\mathrm{Z}}_{\mathrm{k}}$ and $\dot{\mathrm{C}}_{\mathrm{D}, \mathrm{k}}$ are fuel, equipment purchase and the exergy destruction cost rate, respectively.

Exergy destruction cost rate is computed from the following equation[47, 48]:

$$
\dot{C}_{D, k}=c_{F, k} \dot{E} x_{D, k}
$$

In this relation, $\dot{C}_{D, k}(\$ / \mathrm{s})$ is the exergy destruction cost rate in $\mathrm{k}^{\text {th }}$ part of the system $(\$ / \mathrm{s}), c_{F, k}$ is exergy unit cost for input routes of $\mathrm{k}^{\text {th }}$ part of the system $(\$ / \mathrm{MJ})$ and $\dot{E} x_{D, k}$ is exergy destruction rate of $\mathrm{k}^{\text {th }}$ part of the system.

The second objective function is the cost of environmental impact which is calculated by multiplying the cost (US\$/s) of CO and NOx emission in their values of unit damage cost. The values of unit damage cost are as follows [8, 49]:

$$
\begin{aligned}
& C_{C O}=0.02086 \text { US } \$ / \mathrm{kgCO} \\
& C_{\text {NOX }}=6.853 \text { US } \$ / \mathrm{kgNOx}
\end{aligned}
$$

Therefore, the second objective function is as follows:

$$
\dot{C}_{e n v}=C_{C O} \dot{m}_{C O}+C_{N O x} \dot{m}_{N O x}
$$

Both the objective functions considered in this article should be minimized.

\section{OPTIMIZATION METHOD}

\section{MULTI-OBJECTIVE OPTIMIZATION}

Indeed, optimization problems are finding response or responses on a set of possible options with the aim of optimizing criterion or criteria of the problem. The purpose of multi-objective optimization is to find set of Pareto responses on the target function. Also, it is a subcategory from a set of multi-criteria decision-making methods that take place among an infinite set of possible solutions. In these types of problems, unlike the single-objective optimization problems and because of presence of several conflicting objectives, rather than just one solution, a set of solutions should be achieved. In multi-objective optimization, there are a set the solutions that the superior solutions are compared with other solutions in the search space. The remarkable point is that in multi-objective optimization no solution is superior to other one and solution for the problem can be considered regarding the need of designer of each of the Pareto solutions.

\section{MULTI-OBJECTIVE GENETIC ALGORITHM (NSGA-II)}

This algorithm has become a multi-objective algorithm by adding two essential operators to conventional single objective genetic algorithm that instead of finding the best solution, it gives a group of best solutions that is known as Pareto Front. Members of the population fall within the groups, such that members in the first group are a totally nonnominated set by other current members. Members in the second group are also dominated on the same basis only by members of the first group and this process will continue in the same way in other groups so that all the members in each group are assigned one rank based on the number of groups. The general flowchart of multi-objective genetic algorithm (NSGA-II) has been illustrated in Figure 3[50]. 


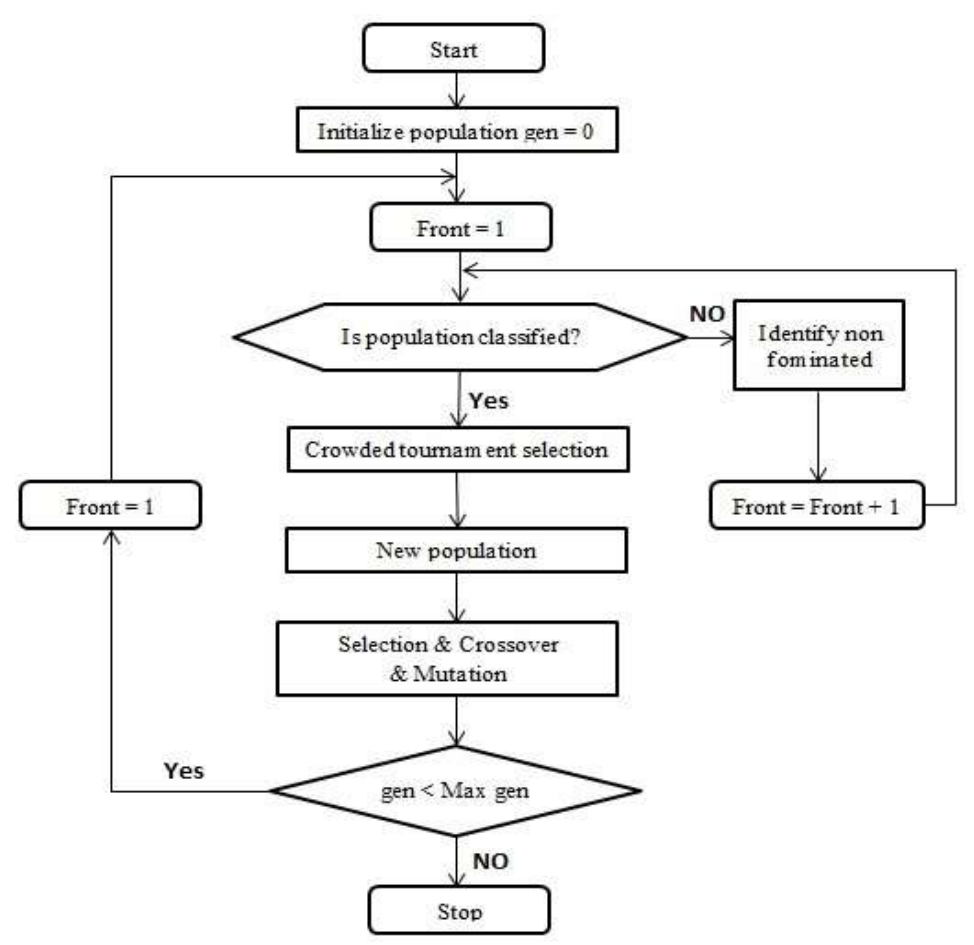

Figure 3. Flowchart of NSGA-II algorithm

\section{RESULTS}

\section{DESIGN VARIABLES}

The number of population and generation was selected 100 and 200 respectively. Mutation Probability and Crossover Probability was considered 0.01 and 0.9 respectively. In addition, the maximum number of iteration was considered 500 , which if this number is reached without the optimization having reached convergence, iteration will stop.

The design variables considered in this paper for the first case cycle (gas turbine cycle with air preheater) are: air compressor pressure ratio $\left(r_{A C}\right)$, combustion chamber inlet temperature $\left(T_{3}\right)$, gas turbine inlet temperature $\left(T_{4}\right)$, air compressor isentropic efficiency $\left(\eta_{A C}\right)$ and gas turbine isentropic efficiency $\left(\eta_{G T}\right)$. In another case, the cycle has been considered without air preheater that design variables in this state are: air compressor pressure ratio, gas turbine inlet temperature, air compressor and gas turbine isentropic efficiency. According to the different conditions of design variables in the optimization process, reasonable constraints have been considered for each variable which is shown in Table 5 .

Table 5. Model constraints

\begin{tabular}{|c|c|}
\hline Constraints & Reason \\
\hline $6 \leq r_{A C} \leq 16$ & Commercial availability \\
\hline $800 \mathrm{~K} \leq T_{3} \leq 1100 \mathrm{~K}$ & Material limitation \\
\hline $1200 \mathrm{~K} \leq T_{4} \leq 1600 \mathrm{~K}$ & Material limitation \\
\hline $0.7 \leq \eta_{A C} \leq 0.9$ & Commercial availability \\
\hline $0.7 \leq \eta_{G T} \leq 0.92$ & Commercial availability \\
\hline
\end{tabular}


In order to validate results of this simulation, the conclusions of this research are compared with the real Aliabad Katoul power plant. The comparison of results is presented in Table 6.

Table 6. Comparison between the power plant real data and simulation

\begin{tabular}{|c|c|c|c|}
\hline Parameter & Power plant data & Simulation Code & Difference (\%) \\
\hline$\dot{C}_{\text {Tot }}($ US $\$ / s)$ & 2.82 & 2.98 & 4.6 \\
\hline$T_{2}(K)$ & 606 & 612 & 1.0 \\
\hline$T_{5}(K)$ & 864 & 879 & 1.7 \\
\hline$T_{6}(K)$ & 672 & 695 & 3.4 \\
\hline
\end{tabular}

\section{THE RESULTS OF MULTI-OBJECTIVE OPTIMIZATION BY GENETIC ALGORITHM}

Figure 4 shows Pareto solution for Aliabad Katoul gas turbine power plant by multi-objective genetic algorithm. It concludes that with increasing in the environmental cost rate, total cost rate decreases. From the figure, it is clear that for the environmental cost rate values from 0.06 (US\$/s) up to 0.1 (US\$/s), total cost rate decreases with a steeper slope. From 0.1 (US\$/s) onwards, the total cost rate decreases slightly while environmental cost rate increases with a steeper slope. In Pareto solution, each solution can be as the optimal answer. Choosing an optimal solution depends on the designer's perspective and importance of each objective function. In the figure, the three points A, B and C are specified. The point $\mathrm{A}$ has the maximum point of total cost rate and the lowest environmental cost. Also, the point $\mathrm{C}$ has the lowest total cost rate and the highest rate of environmental cost. In this study, point B is selected as an optimal point because the goal is optimizing both objective functions simultaneously.

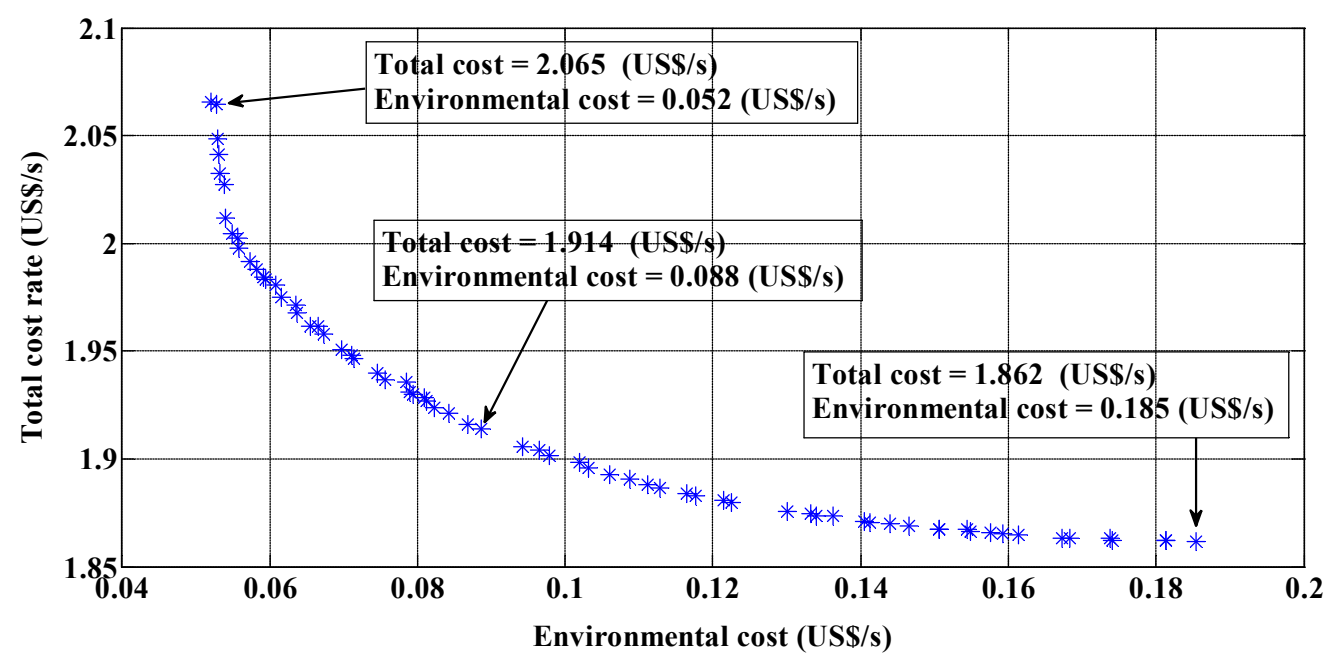

Figure 4. Pareto solution of Aliabad Katoul gas turbine power plant by NSGA-II algorithm

To investigate the effect of air preheater on objective functions, in the second case, the air preheater is removed from Aliabad Katoul power plant cycle so that its effect on objective functions could be studied. In Figure 5, Pareto solution for the studied cycle by eliminating the air preheater has been shown. As it can be seen, the three points A, B and $\mathrm{C}$ are specified. Like Figure 4, the point $\mathrm{A}$ has the highest total cost rate and the lowest environmental cost rate. Also, point $\mathrm{C}$ has the lowest total cost rate and highest environmental cost rate. The results show that by removing of air preheater, values of both objective functions increase. Only at the point $\mathrm{C}$, environmental cost rate is lower than the value 
of point $\mathrm{C}$ in Figure 4, but this point has higher total cost rate. According to the results, it is observed that air preheater existence in the system reduces both objective functions. The values of points A, B and C for both cases are presented in Table 7. The results demonstrate that at the optimum point (point B), for cycle without air preheater, total cost rate is about $30 \%$ and environmental cost rate is about $33 \%$ higher than the cycle with air preheater.

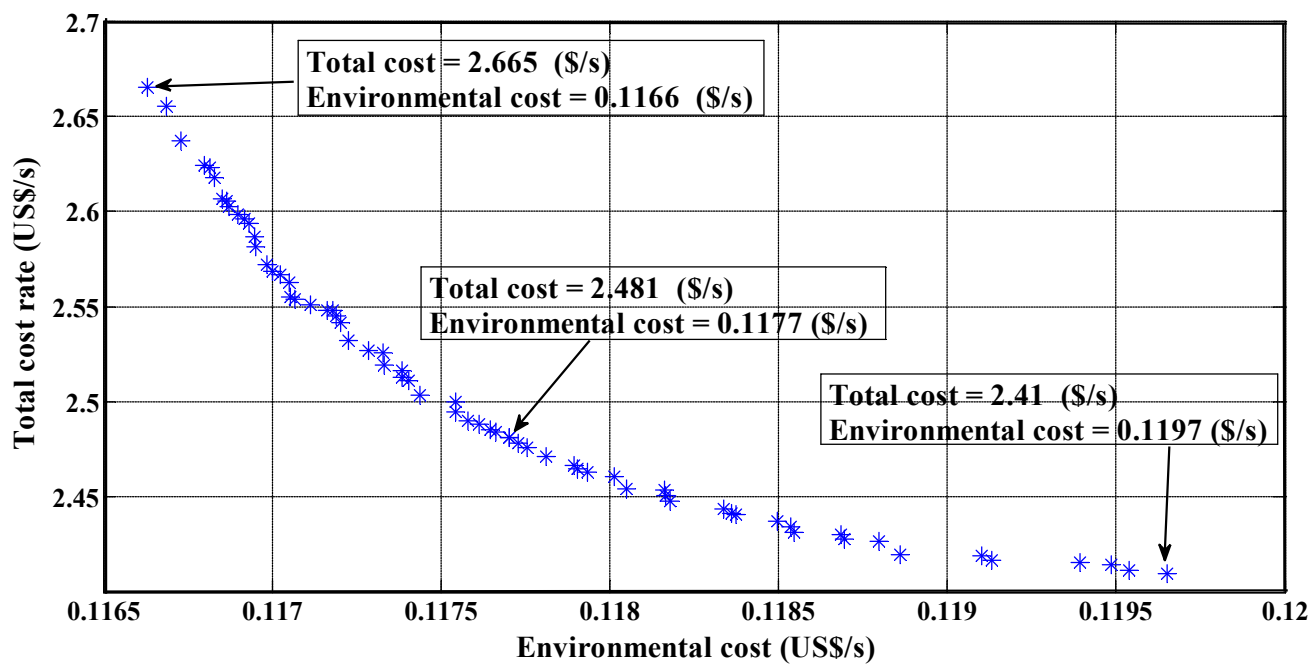

Figure 5. Pareto solution of Aliabad Katoul gas turbine power plant without air preheater by NSGA-II algorithm

Table 7. The objective function values at selected points for two considered cycles

\begin{tabular}{|c|c|c|c|c|}
\hline Cases & Objective function & A point & B point & C point \\
\hline \multirow{3}{*}{\begin{tabular}{c} 
Aliabad power plant cycle \\
\cline { 2 - 5 }
\end{tabular}} & Total cost rate $(U S \$ / s)$ & 2.065 & 1.914 & 1.862 \\
\cline { 2 - 5 } & Environmental cost $(U S \$ / s)$ & 0.052 & 0.088 & 0.185 \\
\hline $\begin{array}{c}\text { Aliabad power plant cycle } \\
\text { without air preheater }\end{array}$ & Total cost rate $(U S \$ / s)$ & 2.665 & 2.481 & 2.41 \\
\cline { 2 - 5 } & Environmental cost $(U S \$ / s)$ & 0.1166 & 0.1177 & 0.1197 \\
\hline
\end{tabular}

\section{DISTRIBUTION OF DESIGN VARIABLES}

In Figures 6a to 10e, distribution of design variables is shown. Upper and lower limits of design parameters are presented by dash lines. Figure 6a shows distribution of Pareto solutions for compressor pressure ratio variable. This distribution shows that the result of changes in this variable within the specified range is in contradiction with both objective functions. Figures $6 \mathrm{~b}$ and $6 \mathrm{c}$, respectively, show distribution of Pareto solutions for inlet temperature of the combustion chamber and gas turbine. As can be seen, distribution of Pareto solutions is close to the specified upper limit which indicates the higher values of these two variables have improved the solution in both objective functions. Most of the solutions for the combustion chamber inlet temperature are about 1005 Kelvin and for the gas turbine inlet temperature is about 1470 Kelvin. Also, Figures $6 \mathrm{~d}$ and 6e, respectively, show distribution of design variables for isentropic efficiency of compressor and gas turbine. It can be seen from these two figures that for the compressor isentropic efficiency, most of the solutions are about $87 \%$ and for the gas turbine isentropic efficiency are about $90 \%$, which indicates that the values of these efficiencies in this range have improved both objective functions. 
Journal of Thermal Engineering, Research Article, Vol. 6, No. 2, Special Issue 11, pp. 180-200, March, 2020

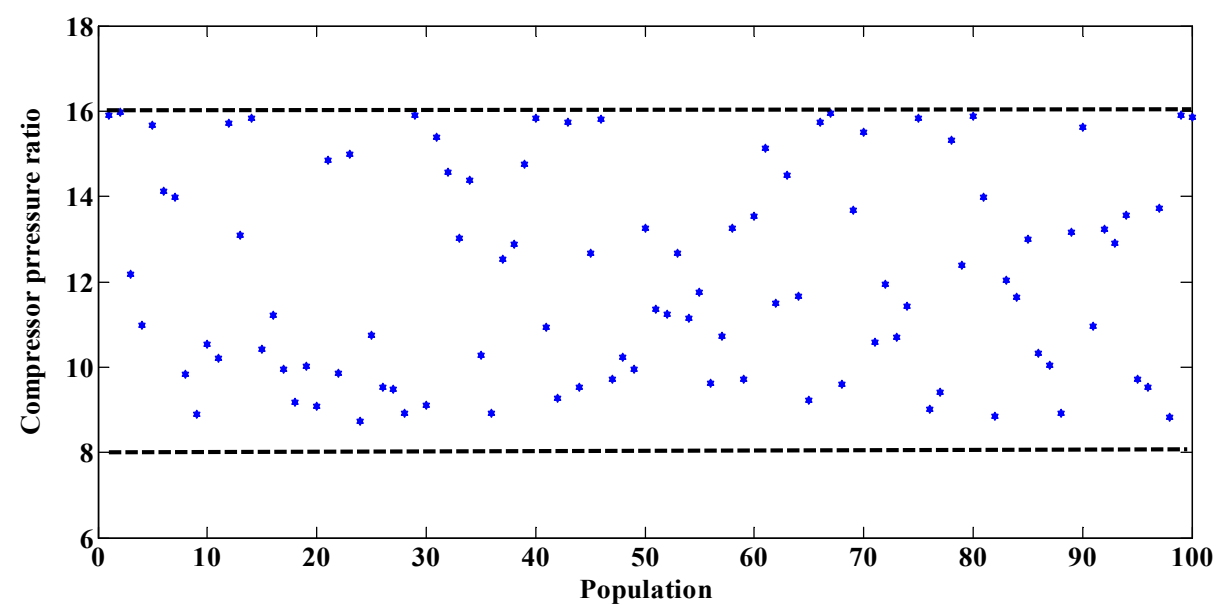

Figure 6a. Distribution of compressor pressure ratio values in Pareto solution

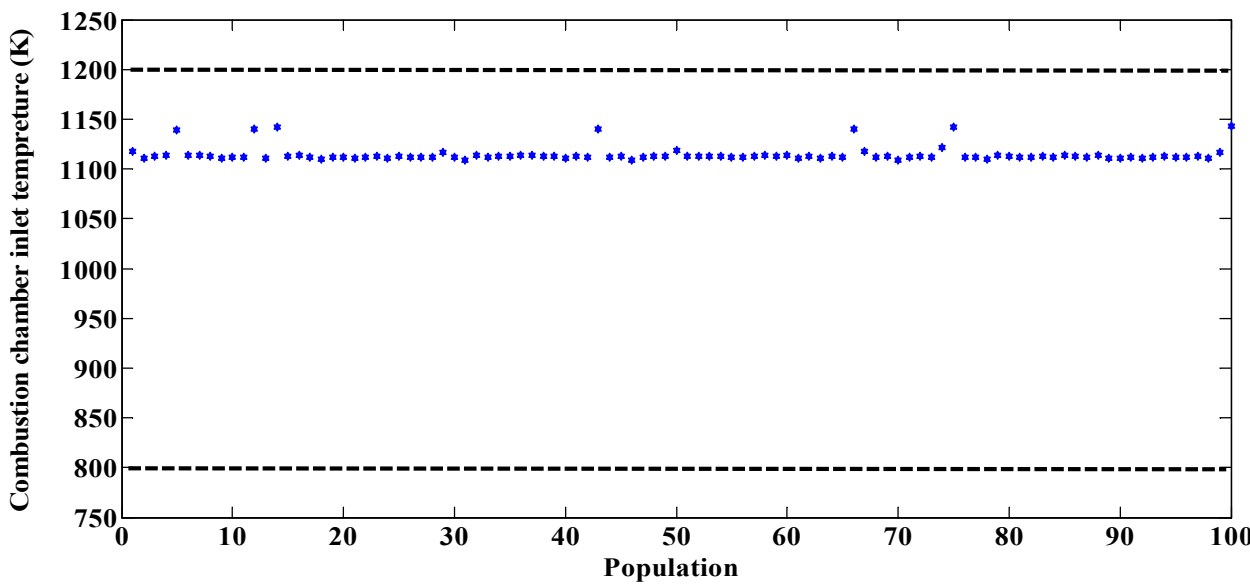

Figure 6b. Distribution of combustion chamber inlet temperature values in Pareto solution

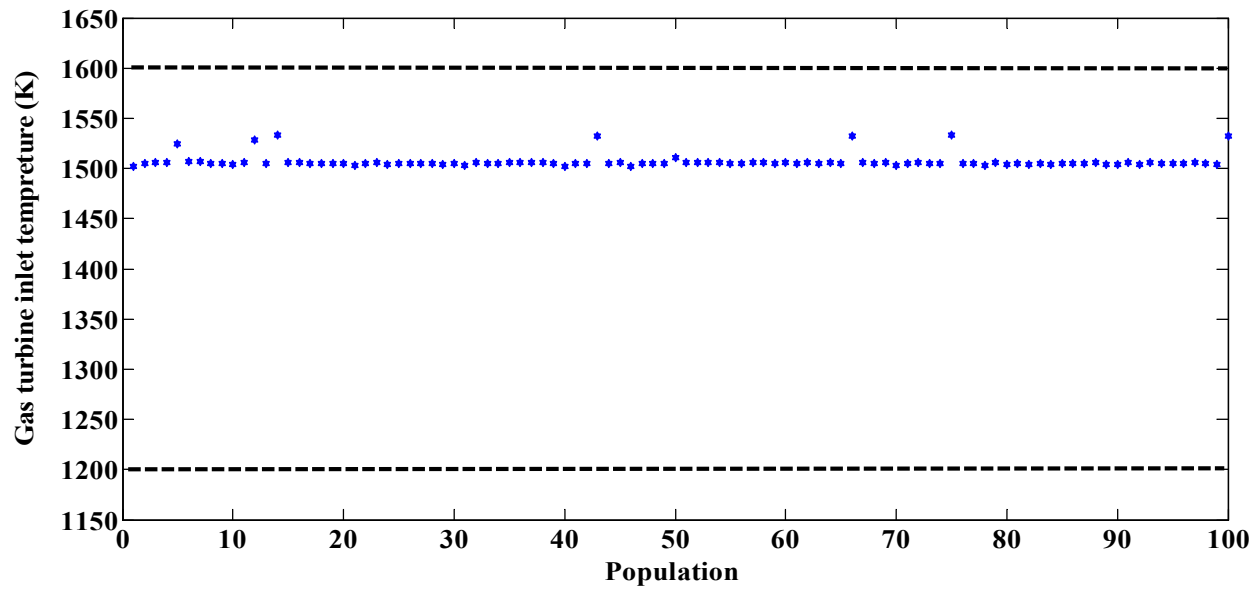

Figure 6c. Distribution of gas turbine inlet temperature values in Pareto solution 


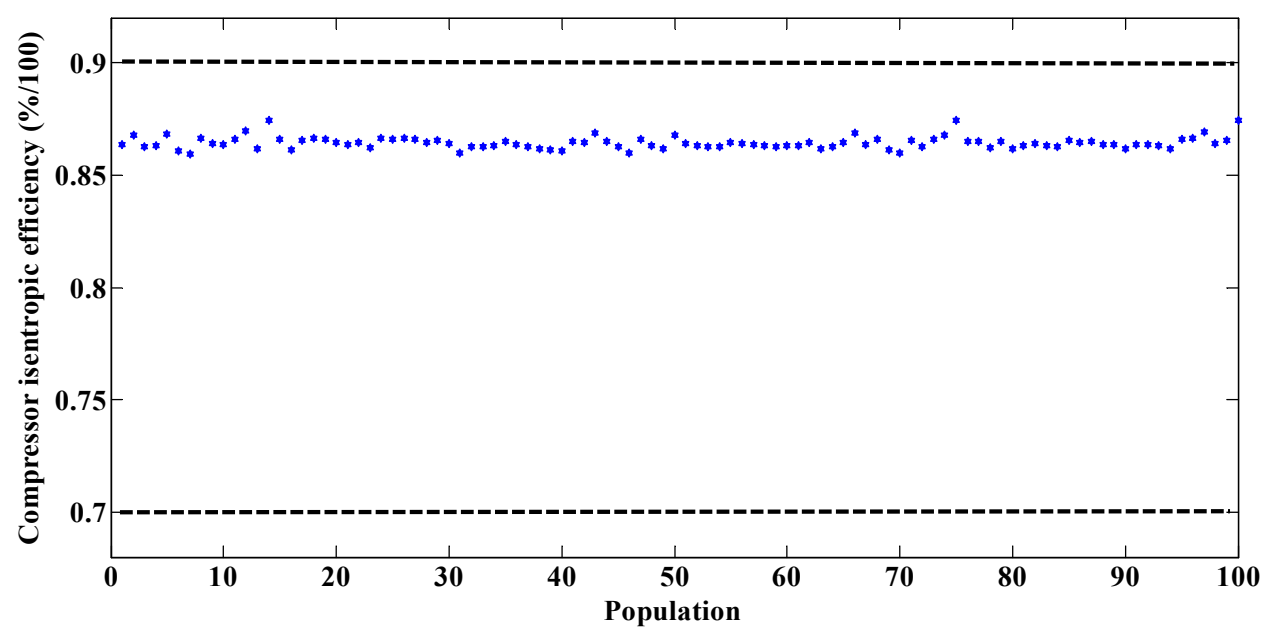

Figure 6d. Distribution of air compressor efficiency values in Pareto solution

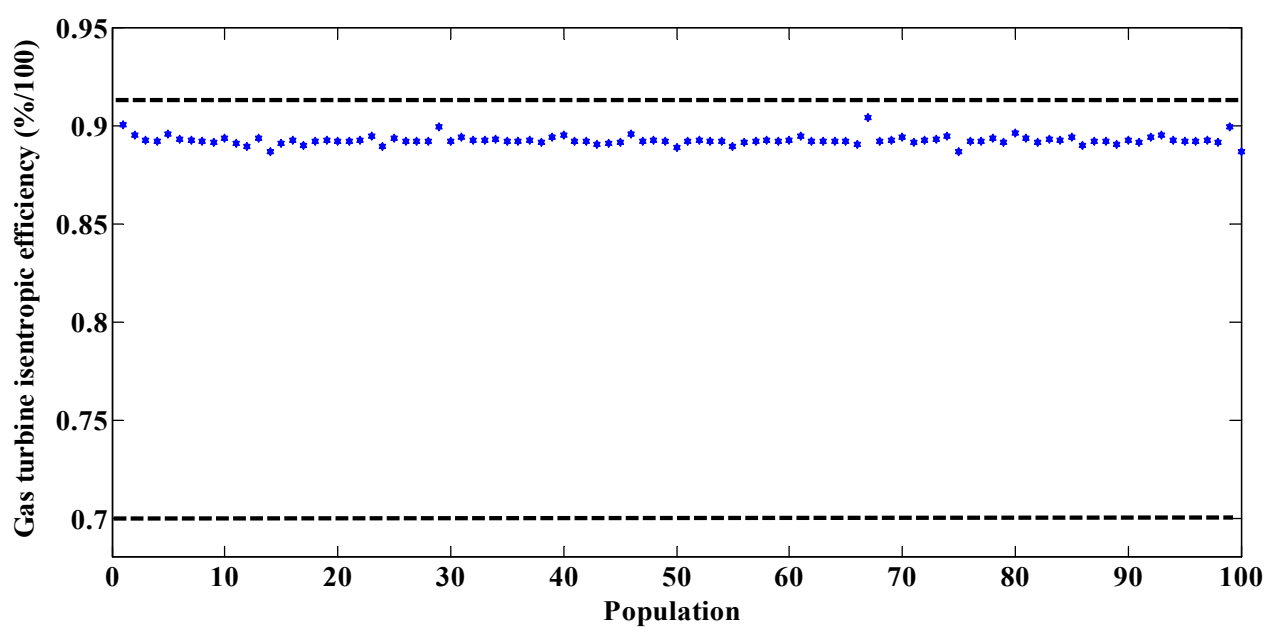

Figure 6e. Distribution of gas turbine efficiency values in Pareto solution

Table 8. The value of design parameter for points A, B and C

\begin{tabular}{|c|c|c|c|}
\hline Parameter & Point A & Point B & Point C \\
\hline$r_{A C}$ & 12.1 & 9.3 & 11.6 \\
\hline$T_{3}$ & 1119 & 1121 & 1128 \\
\hline$T_{4}$ & 1511 & 1504 & 1505 \\
\hline$\eta_{A C}$ & 88.1 & 87.4 & 87.2 \\
\hline$\eta_{G T}$ & 89.8 & 89.1 & 89.3 \\
\hline
\end{tabular}




\section{SENSITIVITY ANALYSIS}

In Figure 7 the sensitivity of objective functions changes to fuel cost per unit of energy is shown. From this figure, it is clear that at lower environmental cost rate, that total cost rate is higher, the sensitivity of Pareto solutions to the fuel unit cost is more than some parts of figure with lower total cost rate. In other words, we can say that sensitivity of fuel unit cost parameter does not have too much effect on cost of environmental impacts.

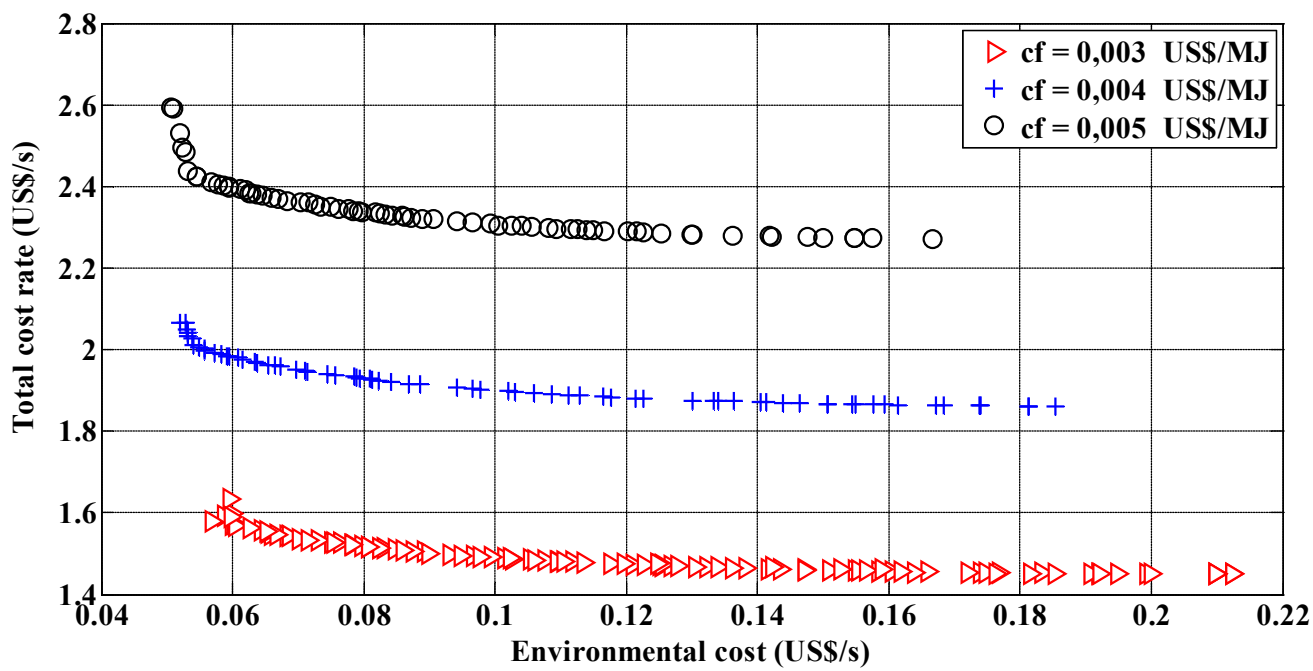

Figure 7. Pareto solution sensitivity to the fuel cost per energy unit

\section{EXERGY DESTRUCTION}

Figure 8 shows exergy destruction values for different parts of the cycle. From this figure it is clear that the maximum rate of exergy destruction is related to the combustion chamber. Exergy destruction is because of three irreversibility factors, which include heat transfer, friction and chemical reaction. Figure 9 shows exergy destruction percentage for different cycle parts. This figure shows that about $73 \%$ of the total exergy destruction is related to the combustion chamber. It decreases by optimizing the air to fuel ratio, reducing exergy destruction and preheating the air before entering to combustion chamber.

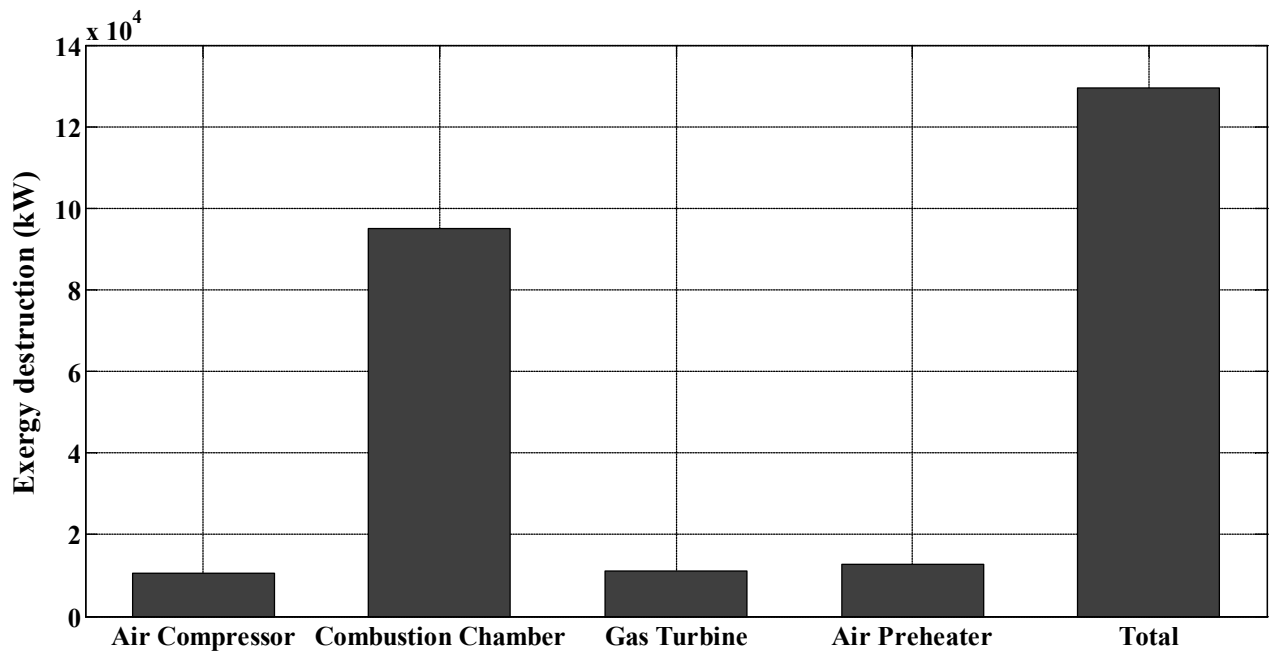

Figure 8. Exergy destruction values for diverse parts 


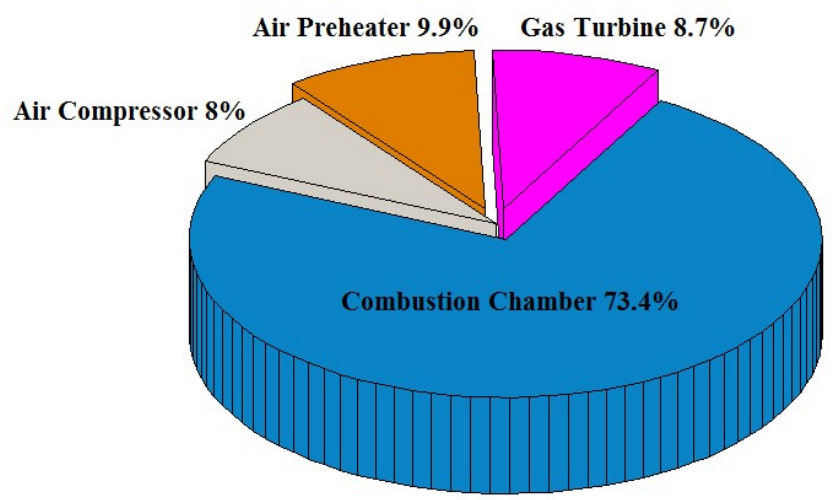

Figure 9. Exergy destruction percentage for diverse cycle parts

Figure 10 shows exergy efficiency changes for different components versus variations in ambient temperature. It is clear that with increasing the ambient temperature, exergy efficiency of all components decreases. By increasing ambient temperature from 293 to $323 \mathrm{~K}$, exergy efficiency of air compressor has decreased from $90 \%$ to $87.7 \%$, exergy efficiency of combustion chamber from $51.9 \%$ to $48.6 \%$, exergy efficiency of gas turbine from $85.4 \%$ to $81.4 \%$ and exergy efficiency of air preheater from $93.9 \%$ to $90 \%$.

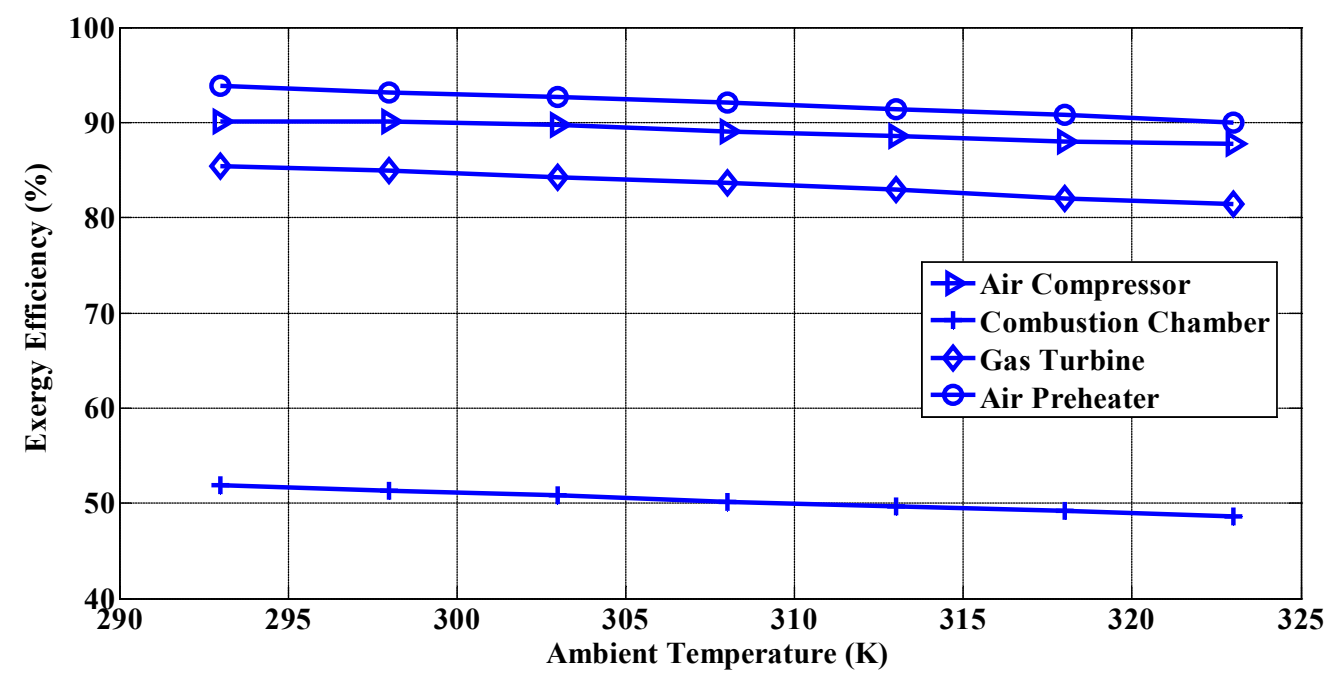

Figure 10. Changes in exergy efficiency for various parts against ambient temperature changes

Figure 11 shows changes in total exergy efficiency against changes in ambient temperature. A growth in ambient temperature diminishes total exergy efficiency. So that with increase of temperature from 293 Kelvin to 323 Kelvin, total exergy efficiency has decreased approximately from $51 \%$ to $49 \%$. It indicates that increasing in ambient temperature has had an adverse impact on exergy efficiency. 


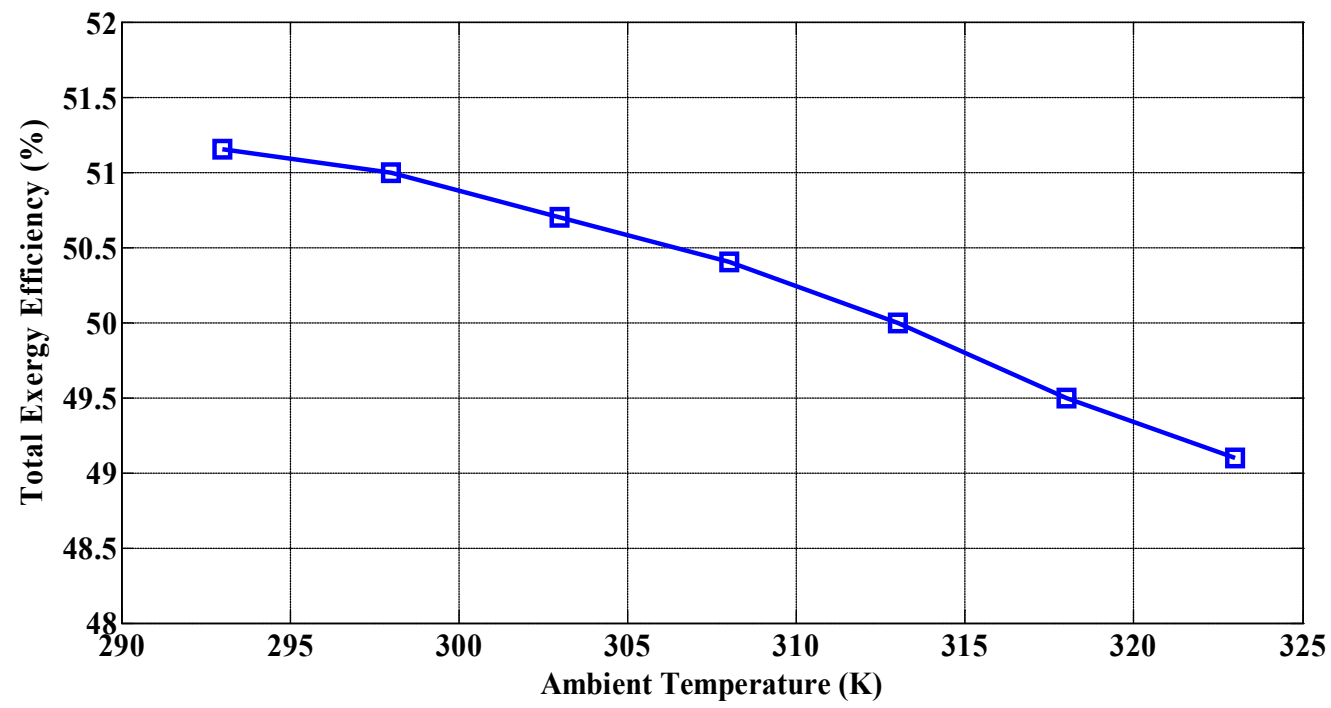

Figure 11. Changes in exergy efficiency against ambient temperature changes

Figure 12 shows changes in exergy destruction for various sectors against changes in ambient temperature. This figure shows that increase in ambient temperature causes exergy destruction of whole parts. So, by increasing the ambient temperature from $293 \mathrm{~K}$ to $303 \mathrm{~K}$, exergy destruction of air compressor, combustion chamber, gas turbine and air preheater have increased $14 \%, 0.6 \%, 18 \%$ and $10 \%$, respectively.

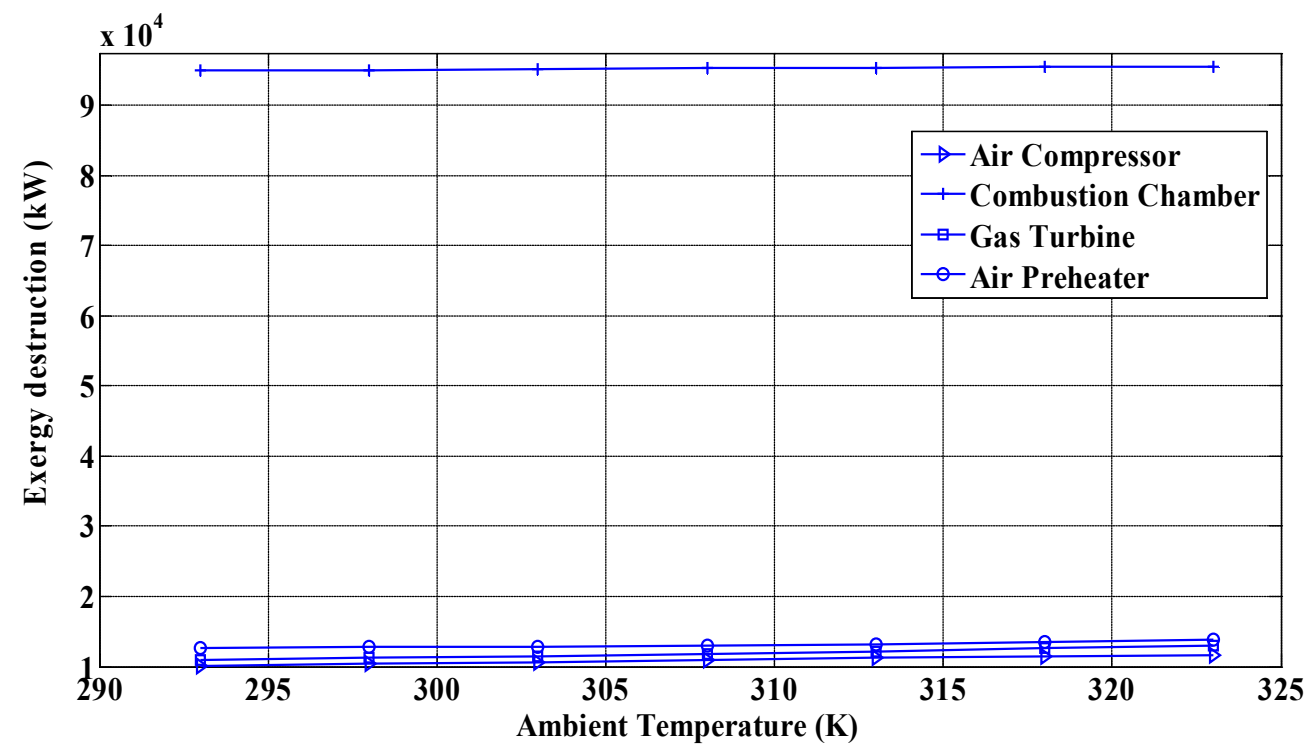

Figure 12. Exergy destruction changes for diverse parts of the cycle against ambient temperature changes

\section{CONCLUSION}

In this paper, Aliabad Katoul gas turbine power plant (northern Iran) was considered thermodynamically, economically environmentally aspects and as well as its optimization by NSGA-II has performed in MATLAB software. The two objective functions considered were: total cost rate and cost of environmental impact. Also, optimization of this cycle has performed in two cases, with air preheater and without it. Also, sensitive analysis of objective functions was 
carried out into changes in fuel cost per unit of energy. Furthermore, the impact of change in ambient temperature on exergy efficiency of each part, also, total exergy efficiency of the cycle was investigated. Briefly following results have concluded:

- Air preheater reduced both objective functions particularly total cost rate.

- In selected optimal point in Pareto solution (point B), for the cycle with air preheater, the total cost rate about $30 \%$ and the environmental cost rate about $33 \%$ were lower than the cycle without air preheater.

- In lower environmental costs, that total cost rate was higher, sensitivity of Pareto solutions to fuel price was more than some parts of the graph with lower total cost rate.

- The highest exergy destruction was related to the combustion chamber.

- With increasing temperature, exergy efficiency of all components was decreased.

- By increasing the ambient temperature, destructions and irreversibility of different components increased.

\section{DECLARATION ON CONFLICT OF INTEREST}

No conflict of interest in this paper existed.

\section{NOMENCLATURE}

$c$

$c_{f}$

$C$

$c_{p}$

LHV

$R$

$h$

$f$

$\dot{E} x$

$\dot{E} x_{D}$

ex

$C R F$

$P$

$T$

$\Delta P$

$r_{A C}$

$\dot{m}$

$s$

$T_{p z}$

$\dot{W}_{n e t}$

$X_{i}$

$N$

Z

$\dot{Z}$

Greek symbols
Exergy unit cost $(U S \$ / M J)$

Fuel exergy unit cost $(U S \$ / M J)$

Cost flow rate $(U S \$ / s)$

Constant pressure heat $(\mathrm{kJ} / \mathrm{kg} . \mathrm{K})$

Lower heating value $(\mathrm{kJ} / \mathrm{kg})$

Gas constant $(\mathrm{kJ} / \mathrm{kg} . \mathrm{K})$

Enthalpy $(\mathrm{kJ} / \mathrm{kg})$

Fuel/air molar ratio

Exergy flow rate $(M W)$

Exergy destruction rate $(M W)$

Specific exergy $(\mathrm{kJ} / \mathrm{kg})$

Capital recovery factor

Pressure (bar)

Temperature $(K)$

Pressure loss

Compressor pressure ratio

Mass flow rate $(\mathrm{kg} / \mathrm{s})$

Specific entropy $(\mathrm{kJ} / \mathrm{kg} \cdot \mathrm{K})$

Adiabatic temperature in the primary zone of combustion chamber $(K)$

Net power output $(M W)$

Molar fraction

Number of hours of plant operation per year

Capital cost of a component (\$)

Capital cost rate $(\$ / s)$

Specific heat ratio

Efficiency

Maintenance factor

Dimensionless temperature

Dimensionless pressure 
$\psi$

$\phi$

Subscripts

a Air

$g \quad$ Combustion gases

ch Chemical

ph Physical

$A C \quad$ Air Compressor

CC Combustion Chamber

GT Gas Turbine

$A P H \quad$ Air Preheater

$D \quad$ Destruction

$k \quad$ Component

Tot Total

env Environmental

0 Reference environment condition

$f \quad$ Natural gas fuel

Ref Reference

$i$

$e$

Inlet condition

Exit condition

\section{REFERENCES}

[1] Kopac M, Hilalci A. Effect of ambient temperature on the efficiency of the regenerative and reheat ÇatalağZ1 power plant in Turkey. Applied Thermal Engineering 2007;27:1377-85. https://doi.org/10.1016/j.applthermaleng.2006.10.029.

[2] Sahoo P. Exergoeconomic analysis and optimization of a cogeneration system using evolutionary programming. Applied Thermal Engineering 2008;28:1580-8. https://doi.org/10.1016/j.applthermaleng.2007.10.011.

[3] Ehyaei M, Mozafari A, Alibiglou M. Exergy, economic \& environmental (3E) analysis of inlet fogging for gas turbine power plant. Energy 2011; 36:6851-61. https://doi.org/10.1016/j.energy.2011.10.011.

[4] Ahmadi P, Dincer I, Rosen MA. Exergy, exergoeconomic and environmental analyses and evolutionary algorithm based multi-objective optimization of combined cycle power plants. Energy 2011;36: 5886-98. https://doi.org/10.1016/j.energy.2011.08.034.

[5] Kaviri AG, Jaafar MNM, Lazim TM. Modeling and multi-objective exergy based optimization of a combined cycle power plant using a genetic algorithm. Energy Conversion and Management 2012;58:94-103. https://doi.org/10.1016/j.enconman.2012.01.002.

[6] Ahmadi P, Almasi A, Shahriyari M, Dincer I. Multi-objective optimization of a combined heat and power (CHP) system for heating purpose in a paper mill using evolutionary algorithm. International Journal of Energy Research 2012;36:46-63. https://doi.org/10.1002/er.1781.

[7] Ahmadi P, Rosen MA, Dincer I. Multi-objective exergy-based optimization of a polygeneration energy system using an evolutionary algorithm. Energy 2012;46:21-31. https://doi.org/10.1016/j.energy.2012.02.005.

[8] Shirazi A, Aminyavari M, Najafi B, Rinaldi F, Razaghi M. Thermal-economic-environmental analysis and multi-objective optimization of an internal-reforming solid oxide fuel cell-gas turbine hybrid system. International Journal of Hydrogen Energy 2012;37:19111-24. https://doi.org/10.1016/j.ijhydene.2012.09.143.

[9] Ahmadi P, Dincer I, Rosen MA. Thermodynamic modeling and multi-objective evolutionary-based optimization of a new multigeneration energy system. Energy Conversion and Management 2013;76:282-300. https://doi.org/10.1016/j.enconman.2013.07.049.

[10] Memon AG, Memon RA, Harijan K, Uqaili MA. Thermo-environmental analysis of an open cycle gas turbine power plant with regression modeling and optimization. Journal of the Energy Institute 2014;87:81-8. https://doi.org/10.1016/j.joei.2014.03.023.

[11] Yazdi MRM, Aliehyaei M, Rosen MA. Exergy, economic and environmental analyses of gas turbine inlet air cooling with a heat pump using a novel system configuration. Sustainability 2015;7:14259-86. 
https://doi.org/10.3390/su71014259.

[12] Ehyaei MA, Tahani M, Ahmadi P, Esfandiari M. Optimization of fog inlet air cooling system for combined cycle power plants using genetic algorithm. Applied Thermal Engineering 2015;76:449-61. https://doi.org/10.1016/j.applthermaleng.2014.11.032.

[13] Khaljani M, Saray RK, Bahlouli K. Comprehensive analysis of energy, exergy and exergo-economic of cogeneration of heat and power in a combined gas turbine and organic Rankine cycle. Energy Conversion and Management 2015;97:154-65. https://doi.org/10.1016/j.enconman.2015.02.067.

[14] Ahmadi A, Ehyaei M. Exergy Analysis a 5kW Polymer Electrolyte Fuel Cell (PEFC) With Cogeneration. ASME 6th International Conference on Fuel Cell Science, Engineering and Technology: American Society of Mechanical Engineers. 2008, p. 491-7. https://doi.org/10.1115/FuelCell2008-65128.

[15] Ahmadi A, Ehyaei M. Exergy analysis of a wind turbine. International Journal of Exergy 2009;6:457-76. https://doi.org/10.1504/IJEX.2009.026672.

[16] AliEhyaei M, Tanehkar M, Rosen MA. Analysis of an Internal Combustion Engine Using Porous Foams for thermal energy recovery. Sustainability 2016;8(3);267. https://doi.org/10.3390/su8030267.

[17] Aliehyaei M, Atabi F, Khorshidvand M, Rosen MA. Exergy, economic and environmental analysis for simple and combined heat and power IC engines. Sustainability 2015;7:4411-24. https://doi.org/10.3390/su7044411.

[18] Asgari E, Ehyaei M. Exergy analysis and optimisation of a wind turbine using genetic and searching algorithms. International Journal of Exergy 2015;16:293-314. https://doi.org/10.1504/IJEX.2015.068228

[19] Ashari G, Ehyaei M, Mozafari A, Atabi F, Hajidavalloo E, Shalbaf S. Exergy, economic, and environmental analysis of a PEM fuel cell power system to meet electrical and thermal energy needs of residential buildings. Journal of Fuel Cell Science and Technology 2012;9:051001. https://doi.org/10.1115/1.4006049.

[20] Z.X.Li, M.A.Ehyaei, H.Kamran Kasmaei, A.Ahmadi,V.Costa. Thermodynamic modeling of a novel solar powered quad generation system to meet electrical and thermal loads of residential building and syngas production. Energy Conversion and Management 2019;199:111982. https://doi.org/10.1016/j.enconman.2019 .111982 .

[21] Chegini S, Ehyaei M. Economic, exergy, and the environmental analysis of the use of internal combustion engines in parallel-to-network mode for office buildings. Journal of the Brazilian Society of Mechanical Sciences and Engineering 2018;40:433. https://doi.org/10.1007/s40430-018-1349-4.

[22] Darvish K, Ehyaei MA, Atabi F, Rosen MA. Selection of optimum working fluid for Organic Rankine Cycles by exergy and exergy-economic analyses. Sustainability 2015;7:15362-83. https://doi.org/10.3390/su71115362.

[23] Ehyaei M, Ahmadi P, Atabi F, Heibati M, Khorshidvand M. Feasibility study of applying internal combustion engines in residential buildings by exergy, economic and environmental analysis. Energy and Buildings 2012;55:405-13. https://doi.org/10.1016/j.enbuild.2012.09.002.

[24] Ehyaei M, Bahadori M. Internalizing the social cost of noise pollution in the cost analysis of electricity generated by wind turbines. Wind Engineering 2006;30:521-9. https://doi.org/10.1260/030952406779994114.

[25] Ehyaei M, Bahadori M. Selection of micro turbines to meet electrical and thermal energy needs of residential buildings in Iran. Energy and Buildings 2007;39:1227-34. https://doi.org/10.1016/j.enbuild.2007.01.006.

[26] Ehyaei M, Farshin B. Optimization of photovoltaic thermal (PV/T) hybrid collectors by genetic algorithm in Iran's residential areas. Advances in energy research 2017;5:31-55. https://doi.org/10.12989/eri.2017.5.1.031.

[27] Ehyaei M, Hakimzadeh S, Enadi N, Ahmadi P. Exergy, economic and environment (3E) analysis of absorption chiller inlet air cooler used in gas turbine power plants. International Journal of Energy Research 2012;36:48698. https://doi.org/10.1002/er.1814.

[28] Ehyaei M, Mozafari A. Energy, economic and environmental (3E) analysis of a micro gas turbine employed for on-site combined heat and power production. Energy and Buildings 2010;42:259-64. https://doi.org/10.1016/j.enbuild.2009.09.001.

[29] Ehyaei M, Mozafari A, Ahmadi A, Esmaili P, Shayesteh M, Sarkhosh M, Dincer I. Potential use of cold thermal energy storage systems for better efficiency and cost effectiveness. Energy and Buildings 2010;42:2296-303. https://doi.org/10.1016/j.enbuild.2010.07.013.

[30] Ehyaei M, Rosen MA. Optimization of a triple cycle based on a solid oxide fuel cell and gas and steam cycles with a multiobjective genetic algorithm and energy, exergy and economic analyses. Energy Conversion and Management 2019;180;689-708. https://doi.org/10.1016/j.enconman.2018.11.023.

[31] Ehyaei MA. Estimation of condensate mass flow rate during purging time in heat recovery steam generator of combined cycle power plant. Thermal Science 2014;18:1389-97. https://doi.org/10.2298/tsci111031102e.

[32] Ehyaei MA, Anjiridezfuli A, Rosen MA. Exergetic analysis of an aircraft turbojet engine with an afterburner. Thermal science 2013;17:1181-94. https://doi.org/10.2298/TSCI110911043E 
[33] Ghasemian E, Ehyaei M. Evaluation and optimization of organic Rankine cycle (ORC) with algorithms NSGAII, MOPSO, and MOEA for eight coolant fluids. International Journal of Energy and Environmental Engineering 2018;9:39-57. https://doi.org/10.1007/s40095-017-0251-7.

[34] Kazemi H, Ehyaei MA. Energy, exergy, and economic analysis of a geothermal power plant. advances in geoenergy research 2018;2:190-209. https://doi.org/10.26804/ager.2018.02.07.

[35] Mozafari A, Ahmadi A, Ehyaei M. Optimisation of micro gas turbine by exergy, economic and environmental (3E) analysis. International Journal of Exergy 2010;7:1-19. https://doi.org/10.1504/IJEX.2010.029611

[36] Mozafari A, Ehyaei M. Effects of regeneration heat exchanger on entropy, electricity cost, and environmental pollution produced by micro gas turbine system. International journal of green energy 2012;9:51-70. https://doi.org/10.1080/15435075.2011.617021.

[37] Rajaei G, Atabi F, Ehyaei M. Feasibility of using biogas in a micro turbine for supplying heating, cooling and electricity for a small rural building. Advances in energy research 2017;5:129-145. https://doi.org/10.12989/eri.2017.5.2.129

[38] Sadeghzadeh H, Aliehyaei M, Rosen MA. Optimization of a Finned Shell and Tube Heat Exchanger Using a Multi-Objective Optimization Genetic Algorithm. Sustainability 2015;7:11679-95. https://doi.org/10.3390/su70911679.

[39] Saidi M, Abbassi A, Ehyaei M. Exergetic optimization of a PEM fuel cell for domestic hot water heater. Journal of Fuel Cell Science and Technology 2005;2:284-9. https://doi.org/10.1115/1.2041672.

[40] Saidi M, Ehyaei M, Abbasi A. Optimization of a combined heat and power PEFC by exergy analysis. Journal of Power Sources 2005;143:179-84. https://doi.org/10.1016/j.jpowsour.2004.11.061.

[41] Shamoushaki M, Ehyaei M, Ghanatir F. Exergy, economic and environmental analysis and multi-objective optimization of a SOFC-GT power plant. Energy 2017;134:515-31. https://doi.org/10.1016/j.energy.2017.06.058.

[42] Shamoushaki M, Ehyaei MA. Exergy, economic and environmental (3E) analysis of a gas turbine power plant and optimization by MOPSO algorithm. Thermal Science 2018;22:2641-51. https://doi.org/10.2298/TSCI161011091S.

[43] Shamoushaki M, Ghanatir F, Ehyaei M, Ahmadi A. Exergy and exergoeconomic analysis and multi-objective optimisation of gas turbine power plant by evolutionary algorithms. Case study: Aliabad Katoul power plant. International Journal of Exergy 2017;22:279-307. https://doi.org/10.1504/IJEX.2017.083160

[44] Yazdi BA, Yazdi BA, Ehyaei MA, Ahmadi A. Optimization of micro combined heat and power gas turbine by genetic algorithm. Thermal Science 2015;19:207-18. https://doi.org/10.2298/TSCI121218141Y

[45] Yousefi M, Ehyaei M. Feasibility study of using organic Rankine and reciprocating engine systems for supplying demand loads of a residential building. Advances in Building Energy Research 2017;13:32-48. https://doi.org/10.1080/17512549.2017.1354779.

[46] Dincer I, Rosen MA. Exergy: energy, environment and sustainable development: Newnes; 2012.

[47] Valero A, Lozano MA, Serra L, Tsatsaronis G, Pisa J, Frangopoulos C, von Spakovsky MR. CGAM problem: definition and conventional solution. Energy 1994;19:279-86.https://doi.org/10.1016/0360-5442(94)90112-0.

[48] Bejan A, Tsatsaronis G, Moran M, Moran MJ. Thermal design and optimization: John Wiley \& Sons; 1996.

[49] Seyyedi S, Ajam H, Farahat S. Thermoenvironomic optimization of gas turbine cycles with air preheat. Proceedings of the Institution of Mechanical Engineers, Part A: Journal of Power and Energy 2011;225:12-23. https://doi.org/10.1177/09576509JPE959.

[50] Senthilkumar C, Ganesan G, Karthikeyan R. Optimization of ECM process parameters using NSGA-II. Journal of Minerals and Materials Characterization and Engineering 2012;11:931. https://doi.org/10.4236/jmmce.2012.1110091. 